\title{
Reologiczna charakterystyka soli kamiennej ze złoża Bytom Odrzański (Polska) w próbie jednoosiowego pełzania
}

\author{
Dagmara Zeljaś (D) \\ AGH Akademia Górniczo-Hutnicza, Wydział Wiertnictwa, Nafty i Gazu, Kraków
}

\begin{abstract}
Streszczenie: W pracy przedstawiono wyniki badań eksperymentalnych próbek soli ze złoża Bytom Odrzański. Sól była poddana badaniom geomechanicznym, w tym reologicznym. Złoże soli Bytom Odrzański jest złożem niezagospodarowanym, o wysokim potencjale wykorzystania dla celów podziemnego magazynowania nośników energii lub składowania odpadów niebezpiecznych, w tym z energetyki jądrowej. Analiza krzywych pełzania posłużyła do określenia parametrów pełzania soli ze złoża Bytom Odrzański. Przedstawione wyniki badań mogą być wykorzystane przy tworzeniu założeń projektowych specyficznych, wielkogabarytowych wyrobisk w złożu soli, które muszą spełniać warunek długotrwałej stateczności. Badania eksperymentalne oraz ustalenie parametrów wytrzymałościowych i reologicznych, a następnie ich analiza są kluczowe dla określenia kryterium zniszczenia danego ośrodka skalnego. Ich znajomość jest wykorzystywana w obliczeniach numerycznych, a także analizach geomechanicznych stateczności podziemnych obiektów w dziedzinie budownictwa podziemnego i szeroko pojętego górnictwa solnego.
\end{abstract}

Słowa kluczowe: pełzanie soli kamiennej, reologia skał, długotrwała stateczność, geomechaniczne własności skały solnej, aproksymacja krzywych doświadczalnych pełzania

\section{RHEOLOGICAL CHARACTERISTICS OF ROCK SALT FROM BYTOM ODRZAŃSKI DEPOSIT (POLAND) IN UNIAXIAL CREEP TEST}

Abstract: The paper presents results of experimental studies based on salt samples from the
Bytom Odrzański deposit. The salt was subjected to geomechanical tests. The Bytom Odrzański
salt deposit is an undeveloped salt deposit with high potential of use for underground storage of
energy carriers or storage of hazardous waste, including nuclear waste. The analysis of creep
curves was used to determine creep parameters of salt from the Bytom Odrzański deposit.
The presented research results can be a basis for creating design assumptions for specific,
large-size excavations in salt deposits, which must meet the condition of long-term stability.
Experimental investigations, determination of strength and rheological parameters and their
analysis are fundamental for determining the failure criterion of a given rock medium. Their
know-ledge is used in numerical calculations, geomechanical analyses of stability of under-
ground structures in the field of underground construction and widely understood salt mining.
Keywords: rock salt creep, rock rheology, long-term stability, geomechanical properties of salt
rock, approximation of experimental creep curves https://doi.org/10.7494/978-83-66727-47-2_11 


\section{Wprowadzenie}

Wśród zagadnień, którymi zajmuje się geomechanika, znajduje się rozpoznawanie własności mechanicznych i reologicznych skał. Znajomość charakterystyki reologiczno-mechanicznej górotworu jest niezbędna w analizie stanu naprężenia i odkształcenia górotworu w pobliżu wyrobisk wykonywanych metodą otworową lub metodami górniczymi.

W dobie eksploracji przez człowieka złóż zalegających na dużych głębokościach i wykorzystania wyrobisk poeksploatacyjnych jako podziemnych magazynów nośników energetycznych lub składowisk odpadów lokalizowanych w złożach soli istnieje potrzeba rozpoznania własności geomechanicznych złóż o wysokim potencjale wykorzystania w przyszłości. Naruszony działalnością człowieka górotwór charakteryzuje się specyficznym stanem naprężenia (Tajduś i in. 2012), mającym wpływ na zachowanie stateczności posadowionych w nim obiektów (np. kawern do magazynowania gazu lub wielkogabarytowych komór przeznaczonych do składowania odpadów niebezpiecznych). Te wyrobiska muszą zachować określony kształt i wielkość pomimo działających na nie sił dążących do zmiany stanu równowagi. Statecznością wyrobiska jest jego trwałość. Wyrobisko musi być funkcjonalne w długim okresie (kawerny magazynowe nośników energii projektowane są na kilkadziesiąt lat, a podziemne składowiska odpadów z energetyki jądrowej - na kilkaset lat). W takim przypadku mówi się o długotrwałej stateczności. Obiekty wykonane metodami górniczymi czy wiertniczymi w złożu soli są specyficzne. Ulegają one na skutek intensywnych zjawisk reologicznych w górotworze konwergencji, czyli przemieszczania się górotworu w kierunku wybranych przestrzeni. Ta sytuacja stanowi problem podczas wieloletniego eksploatowania wyrobisk, dlatego już na etapie projektowania i wykonywania wyrobisk należy uwzględniać zmiany ich konwergencji (Kłeczek 1994).

W wyniku ingerencji w górotwór i utworzenia wyrobiska narusza się pierwotny stan naprężenia, który przechodzi we wtórną równowagę. W przypadku wyrobiska zlokalizowanego w górotworze solnym bezpośrednio po jego wykonaniu panuje sprężysty stan naprężenia. W miarę upływu czasu i stabilizacji naprężeń może wystąpić kruche zniszczenie struktury górotworu lub jego plastyczne płynięcie. Stateczność wyrobisk jest zagadnieniem skomplikowanym, wymaga uwzględnienia kilku czynników, takich jak bezpieczeństwo, względy ekologiczne i opłacalność przedsięwzięcia. Zarówno nagła utrata stateczności (zawał wyrobisk), jak i zaciskanie wyrobiska w długim czasie są niekorzystne, bo wiążą się zaprzestaniem pełnienia przez wyrobisko jego funkcji.

Analizie poddano skałę soli kamiennej pochodzącej z cechsztyńskiej formacji solonośnej o wykształceniu złoża pokładowego zalegającego w południowo-zachodniej 
części Polski, zlokalizowanego w pobliżu Lubińsko-Głogowskiego Okręgu Miedziowego (rys. 1). W obszarze Bytomia Odrzańskiego pokładowe złoże soli ma miąższość sięgającą do $260 \mathrm{~m}$ (Preidl 1990). Strop złoża znajduje się na głębokości poniżej 1000 m p.p.t. Ze złoża z otworu S-478, znajdującego się w dogodnej lokalizacji dla przyszłych inwestycji (Ślizowski i Urbańczyk 2011, Lankof 2018), pobrano rdzeń (tab. 1), z którego wykonano próbki. Materiał był poddany wstępnej selekcji. Próba badawcza miała kształt walca o stosunku wymiarów podłużnych $(h=120 \mathrm{~mm})$ do poprzecznych $(d=60 \mathrm{~mm})$ równym $h / d=2$. Przygotowując ją, zadbano, by została zachowana równoległość podstaw próbki w stosunku do pobocznicy walca. Dla zapewnienia maksymalnego podobieństwa próbek poddano je selekcji metodą impulsów ultradźwiękowych. Brano pod uwagę fakt, że prędkość przejścia fali ultradźwiękowej jest funkcją gęstości badanego materiału, zatem do badań wybrano takie próbki (Śliwiński 2001), dla których rozrzut pomierzonych prędkości fali ultradźwiękowej był najmniejszy i nie przekraczał $\pm 5 \%$. Wyselekcjonowano trzy próbki, które poddano próbom pełzania w jednoosiowym stanie naprężenia, a rezultaty stanowią uśrednione wartości parametrów pełzania soli z tego złoża przy naprężeniu pionowym $23 \mathrm{MPa}$. Dobór wartości naprężenia obciążającego próbkę wynikał z warunków, jakim poddana jest sól z tego złoża w miejscu zalegania, a więc głębokości zalegania i średniego obciążenia, jakie wywierają skały w nadkładzie.

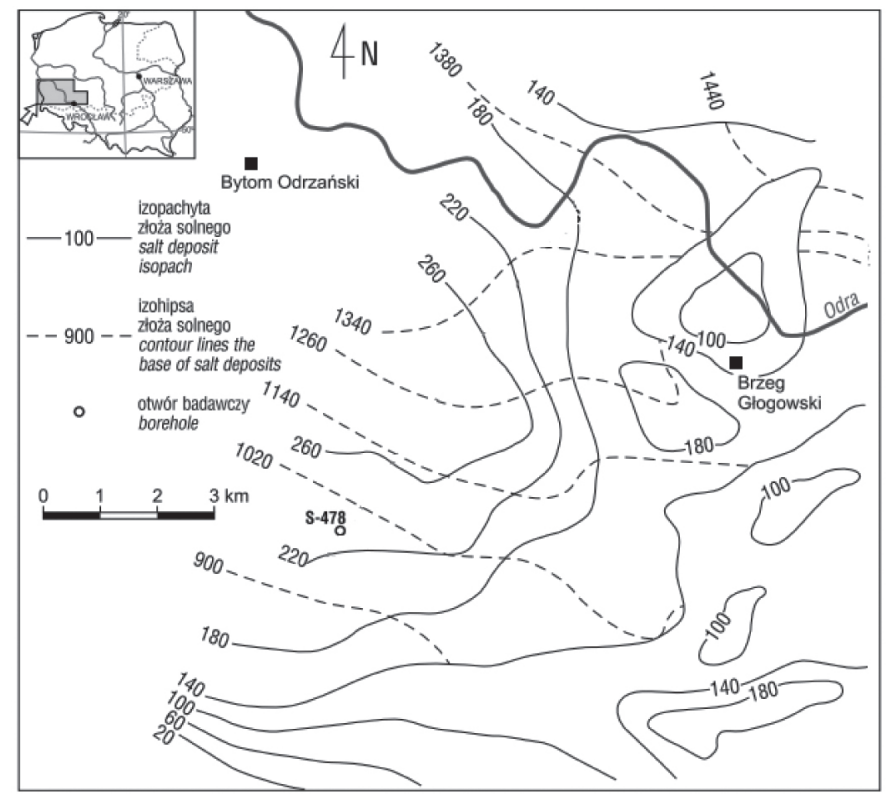

Rys. 1. Fragment mapy złoża soli Na1 koło Bytomia Odrzańskiego Źródło: Szybist (1984) 


\section{Tabela 1}

Profil geologiczny otworu badawczego S-478, z którego pochodzą próby do badań

\begin{tabular}{|c|c|c|c|}
\hline Lp. & Głębokość zalegania [m p.p.t.] & Miąższość warstwy [m] & Opis warstwy \\
\hline 1 & $0-14$ & 14,0 & czwartorzęd \\
\hline 2 & $14-395$ & 381,0 & trzeciorzęd \\
\hline 3 & $395-767,5$ & 372,5 & pstry piaskowiec \\
\hline 4 & $767,5-793,0$ & 25,5 & iłowiec \\
\hline 5 & $793,0-902,5$ & 109,5 & anhydryt górny \\
\hline 6 & $902,5-1139,0$ & 236,5 & sól kamienna \\
\hline 7 & $1139,0-1171,2$ & 32,5 & anhydryt dolny \\
\hline 8 & $1171,2-1171,8$ & 0,6 & biały spagowiec \\
\hline 9 & $1171,8-1184,0$ & 12,2 & czerwony spagowiec \\
\hline
\end{tabular}

\section{Metody badawcze}

Próba pełzania wykonana w laboratorium geomechanicznym polega na obciążeniu próbki laboratoryjnej do poziomu założonego naprężenia $\left(\sigma_{0}\right)$, gdy warunki się stabilizują rozpoczyna się właściwe badanie (rys. 2). Polega ono na pomiarze odkształceń $(\varepsilon)$ próbki w czasie.

W próbie pełzania, gdy zadana jest historia naprężenia, rejestrowaną odpowiedzią materiału skalnego jest historia odkształcenia (rys. 2).

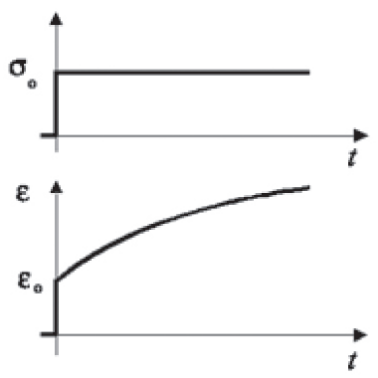

Rys. 2. Krzywa pełzania $\varepsilon=f(t) \mathrm{w}$ warunkach ustalonych, gdzie $\sigma=\sigma_{0}=$ const

Równanie stanu w postaci $f\left(\sigma_{0}, \varepsilon, t\right)=0$ charakteryzuje próbę pełzania. Funkcję pełzania przedstawia natomiast równanie:

$$
\varphi(t)=\varepsilon(t) / \sigma_{0}
$$


Obserwacja zjawiska pozwala na wysunięcie wniosków dotyczących charakteru zachowania się skały w projektowanych warunkach i mechanizmu jej zniszczenia. Efektem badań jest wyznaczenie stałych materiałowych (współczynnika sprężystości, wspóczynnika lepkości). Modelowy przebieg zjawiska pełzania pokazano na rysunku 3 (Reza Taheri i in. 2020).

Pełne zjawisko pełzania obejmuje trzy fazy pełzania:

faza I - pełzanie początkowe - pierwotne, prędkość odkształceń (de/dt) maleje zjawisko utożsamiane ze zjawiskiem umocnienia skały;

faza II - pełzanie ustalone, prędkość odkształceń jest stała ( $\mathrm{d} \varepsilon / \mathrm{d} t=$ const);

faza III - pełzanie końcowe, prędkość odkształceń $(\mathrm{d} \varepsilon / \mathrm{d} t)$ rośnie.

Dostatecznie długie utrzymanie warunków obciążenia próbki prowadzi do dekohezji i zniszczenia próbki.

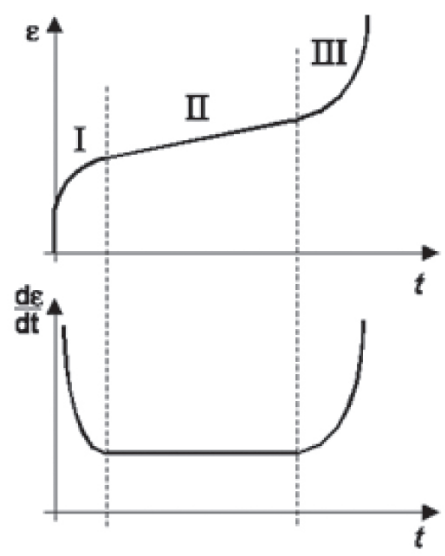

Rys. 3. Fazy pełzania

Próba pełzania często jest utożsamiana z próbą wytrzymałości czasowej, obciążenie wywierane na próbkę jest utrzymywane aż do momentu jej zniszczenia. Właściwość zjawisk reologicznych powodująca, że materiał ulega zniszczeniu przy dowolnej wartości przyłożonego naprężenia utrzymywanego w odpowiednio długim czasie, jest jedną z najistotniejszych różnic w zachowaniu się materiałów reologicznych w porównaniu z materiałami o własnościach niezależnych od czasu.

Badania przeprowadzono w urządzeniu przystosowanym do pomiarów w jednoosiowym stanie naprężenia. Schemat wykorzystanej pełzarki (patent nr 57129/1969) przedstawiono na rysunku 4 (Kłeczek i Filcek 1969).

Próby reologicznego pełzania przeprowadza się przy różnych poziomach obciążenia ściskającego (pomiędzy zerem a obciążeniem krytycznym $R_{c}$ ). Prace eksperymentalne odbywały się w warunkach ustalonych przy stałym naprężeniu pionowym $\sigma_{z}$ i temperaturze $T=23^{\circ} \mathrm{C}$. 


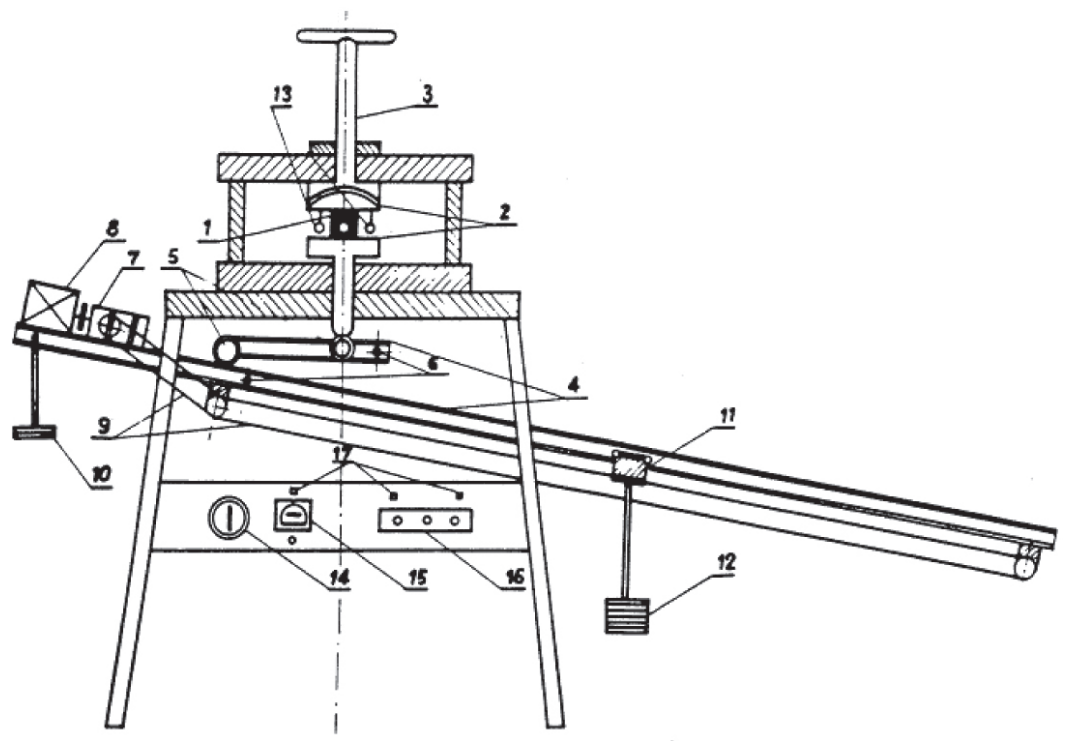

Rys. 4. Schemat urządzenia do badania odkształceń próbki pod wpływem stałego obciążenia: 1 - próbka solna, 2 - płyty oporowe do przenoszenia osiowego obciążenia próbki, 3 - śruba dociskowa górnej płyty oporowej, 4 - dźwignia obciążenia dolnej płyty oporowej, 5 - krzywki przenoszące obciążenie w układzie dźwigni, 6 - punkty obrotu dźwigni, 7 - układ redukcyjny napędu, 8 - silnik napędu z regulowaną ilością obrotów, 9 - łańcuch tulejowo-drabinkowy transmisji napędu, 10 - obciążniki torowania układu dźwigni, 11 - suwnica obciążenia, 12 - obciążniki układu dźwigni, 13 - tensometry odkształceń próbki, 14 - wyłącznik główny układu napędowego, 15 - licznik czasu, 16 - przyciski sterowania układu „obciążenie-odciążenie”, 17 - wskaźniki kontrolne układu sterowania napędu Źródło: Kłeczek i Filcek (1969)

Na podstawie zmierzonych liniowych bezwzględnych odkształceń podłużnych $\left(\lambda_{\mathrm{z}}\right)$ obliczono wartości odkształceń jednostkowych podłużnych $\left(\varepsilon_{z}\right)$ :

$$
\varepsilon_{z}=\frac{\lambda_{z}}{h}
$$

gdzie $h$ - wysokość próbki.

Graficzna interpretacja odkształceń pionowych $\varepsilon_{z}$ została przedstawiona jako zależność $\varepsilon_{z}=f(t)$, co pokazano na rysunku 2 .

Doświadczalne krzywe pełzania $\varepsilon_{z}=f(t)$ aproksymowano funkcjami, które odpowiadają pełzaniu w modelach reologicznych Maxwella, Poytinga-Thomsona i Burgersa, modelu całkowym z potęgowym jądrem pełzania Abela oraz modelu potęgowym Nortona. Charakterystyka pełzania w tych modelach została zawarta w tabeli 2. 


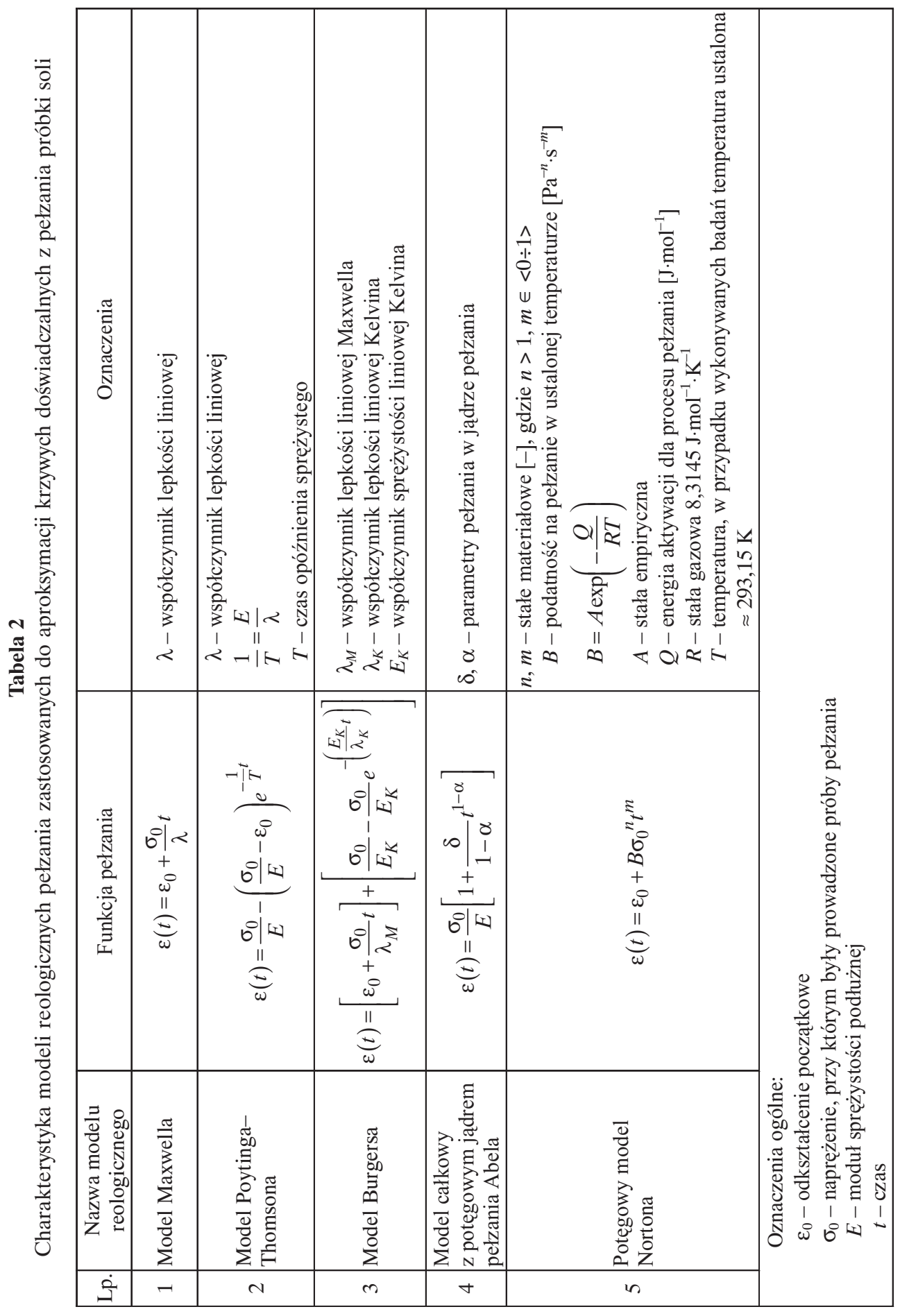


Aproksymacje wykonano przy zastosowaniu modeli najlepiej odwzorowujących ośrodki o właściwościach lepkoplastycznych (Flisiak i Kolano 2012, Firme i in. 2016, Zhou i in. 2018, Reza Taheri i in. 2020, Zhang i in. 2021). Celem aproksymacji był dobór modelu reologicznego pełzania, który pozwoli na określenie konstytutywnego równania stanu skały solnej pochodzącej ze złoża Bytom Odrzański. Uzyskanie najwyższego współczynnika dopasowania krzywej aproksymowanej pozwoliło na wskazanie modelu najlepiej odzwierciedlającego własności badanej soli. Współczynnik dopasowania określony został przez zastosowanie metod statystycznych oraz określenie korelacji i wyznaczenie funkcji regresji dla uśrednionej krzywej doświadczalnej przy naprężeniu $23 \mathrm{MPa}$. Liczba modeli reologicznych i zaprezentowana aproksymacja nimi krzywej doświadczalnej wynikają z wcześniejszych doswiadczeń oraz możliwości wykorzystania niektórych modeli w symulacjacjach numerycznych i określonych programach stosowanych do prognozowania zachowania charakterystycznej skały solnej w praktycznych rozwiązaniach geomechanicznych (Pałac-Walko i Pytel 2010).

\section{Wyniki badań i dyskusja}

Założony harmonogram badań, który pozwoliłby określić stałe materiałowe soli, obejmował dwie fazy pełzania. Badana sól osiągała w fazie pierwszej prędkości odkształceń odpowiadające fazie pełzania pierwotnego, gdzie prędkość odkształceń maleje. Faza ta trwała 75250 s, następnie próbka weszła w fazę pełzania stacjonarnego charakteryzującą się stałą prędkością pełzania równą średnio $15 \mathrm{~mm} / \mathrm{mm} \cdot \mathrm{s}^{-1}$, która utrzymywała się do końca trwania próby, czyli 700000 s (rys. 5b). Istnieje duże prawdopodobieństwo, przy dłuższym utrzymaniu warunków pełzania, że przy naprężeniu $23 \mathrm{MPa}$ prędkość pełzania zaczęłaby narastać, a próba przeszłaby w fazę pełzania progresywnego. Charakter krzywej pełzania (rys. 5a) jasno świadczy o tym, że w próbce nie występuje tendencja do wygaszania przyrostu odkształceń w czasie, ten przyrost jest w miarę równomierny.

Analiza przebiegu krzywej doświadczalnej (nieliniowej) pełzania skłoniła do jej aproksymacji znanymi modelami reologicznymi, które znajdują zastosowanie w analizie reologicznych własności skały solnej. Wyniki analiz przedstawiono na wykresach pełzania $\varepsilon_{z}=f(t)$, gdzie krzywa doświadczalna była aproksymowana każdym z pięciu modeli reologicznych (rys. 6), natomiast $w$ tabeli 3 zestawiono dane o wyznaczonych parametrach pełzania każdym z modeli. Najlepsze dopasowanie uzyskano, aproksymując krzywą doświadczalną modelami bardziej złożonymi (Burgersa, całkowym z potęgowym jądrem Abela i potęgowym Nortona) - otrzymano korelację praktycznie pełną $(0,997)$. Skała solna ulega deformacji, a powstające odkształcenia są odkształceniami 
nieodwracalnymi. Celem analizy krzywej pełzania i jej aproksymacji było określenie parametrów lepkosprężystych soli zestawionych w tabeli 3. Znajomość parametrów lepkości skały, podatności na proces pełzania, modułu sprężystości i czasu opóźnienia sprężystego jest ważna w procesie oceny stateczności górotworu. Obecnie wyznaczone w badaniach laboratoryjnych parametry implementuje się do specjalistycznych programów komputerowych w celu wykonania symulacji numerycznych odzwierciedlających rzeczywistą budowę i przebieg eksploatacji wielkogabarytowych wyrobisk w złożach soli wykonywanych metodą otworową lub konwencjonalnymi metodami górniczymi. Możliwość aproksymacji krzywych pełzania różnymi modelami pozwala na określenie różnych parametrów reologicznych i - w zależności od dalszych działań obliczeniowych i możliwości programów symulacyjnych - wykorzystanie tych danych w procesie projektowania i oceny stateczności obiektów w długim horyzoncie czasowym.
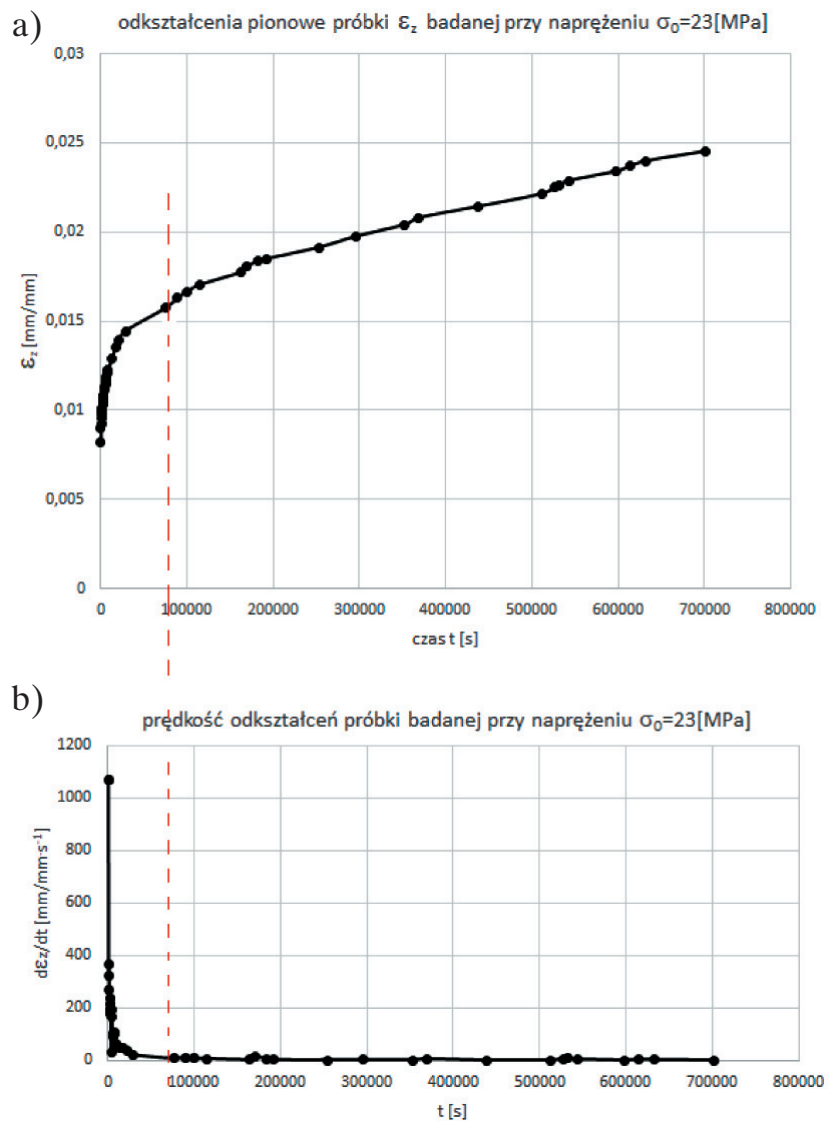

Rys. 5. Wykres pełzania soli $\varepsilon_{z}=f(t)$ przy stałym naprężeniu $\sigma=23 \mathrm{MPa}$ (a) oraz odpowiadający mu wykres prędkości odkształceń $\left(\mathrm{d} \varepsilon_{z} / \mathrm{d} t\right)$ w fazie pełzania pierwotnego i ustalonego (b) 


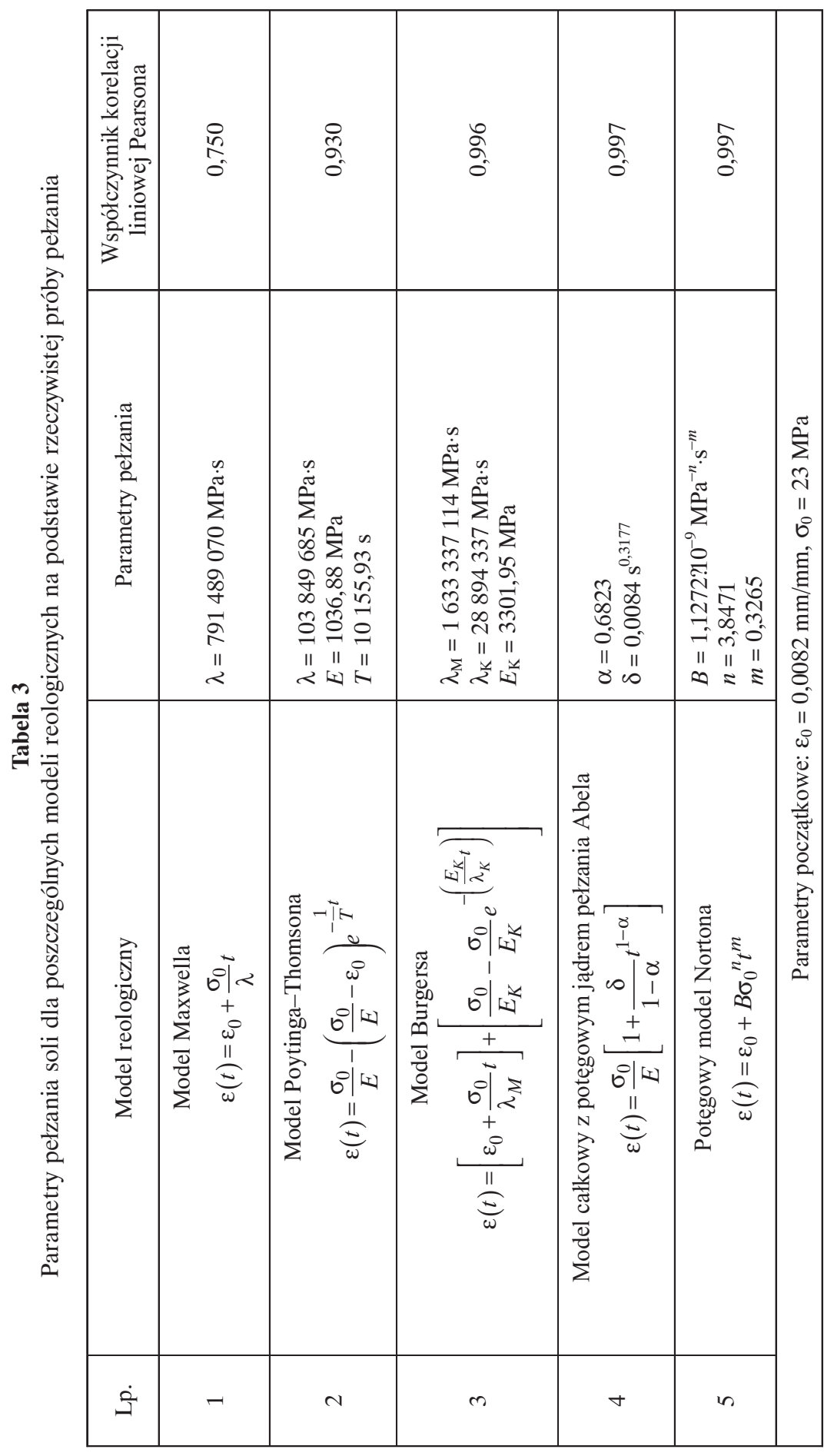




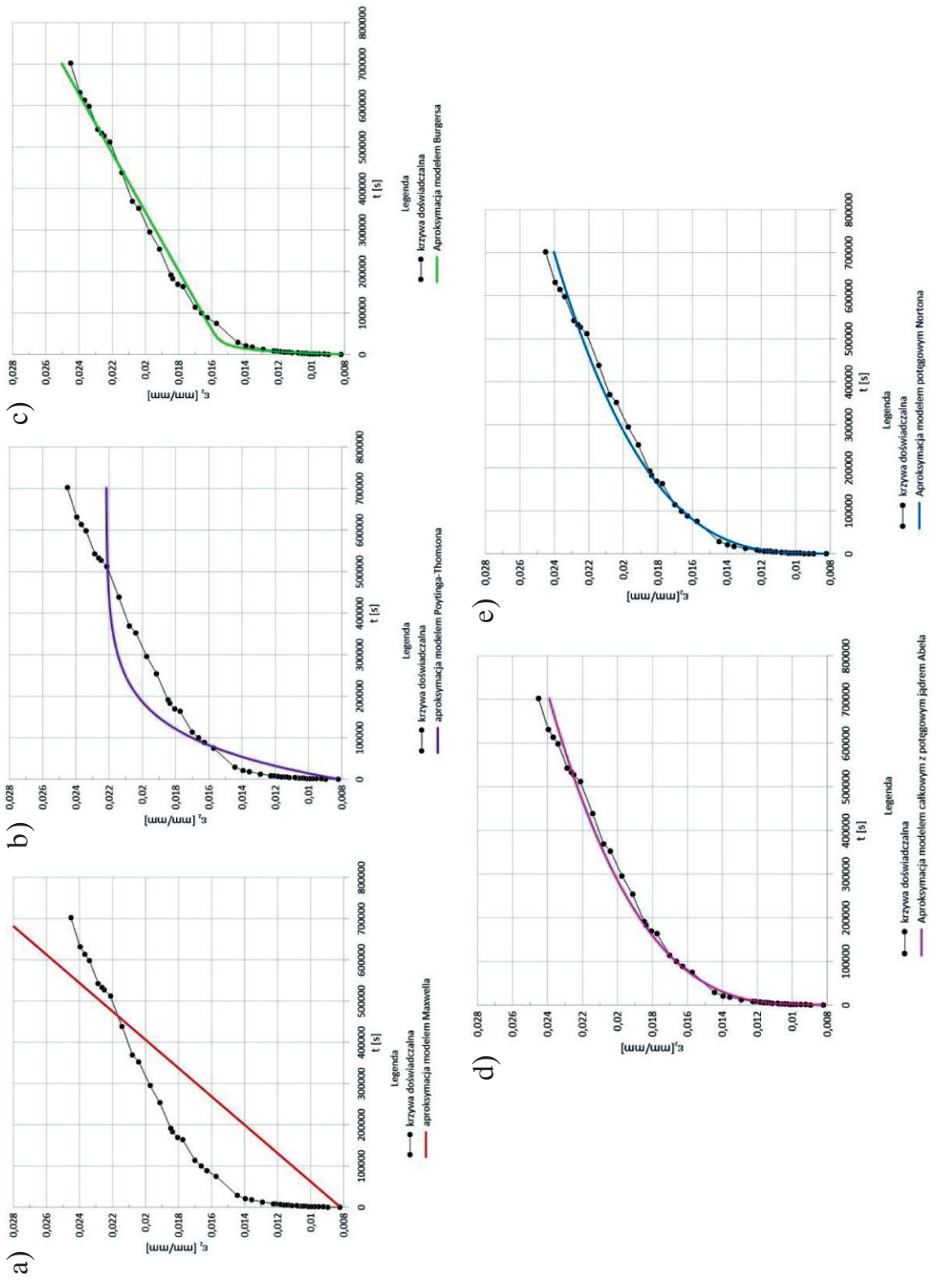

$\hat{\theta}$

\begin{tabular}{l}
\multirow{2}{0}{} \\
0 \\
0 \\
0 \\
0 \\
0
\end{tabular}

อิ

픙

है

E

䆶

哓

용

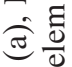

$\stackrel{\pi}{=}$



预

ह ह

氙 $\frac{\pi}{80}$

릉

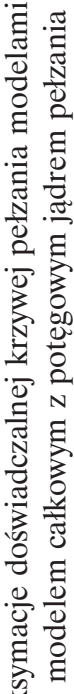

는 


\section{Podsumowanie}

Górotwór solny wykorzystywany do lokalizowania w jego wnętrzu wielkogabarytowych pustek o różnym przeznaczeniu pracuje w niekorzystnych warunkach temperaturowo-naprężeniowych. Podobnie jak w przypadku innych materiałów konstrukcyjnych jego trwałość jest ograniczona. Ograniczenie to związane jest z malejącą przydatnością takich obiektów w funkcji czasu. Przydatność wyrobisk górniczych projektowanych i realizowanych w złożach solnych, typu podziemna kawerna magazynowa, szacowana jest na minimum kilkadziesiąt lat, a w przypadku wielkogabarytowych komór składowiska na setki lat. Te specyficzne wielkogabarytowe wyrobiska górnicze w złożu soli, pracujące w warunkach zmiennych ciśnień wewnętrznych i zmian temperatur, muszą zachować długotrwałą stateczność oraz szczelność (Kunstman i in. 2002). Najcenniejszym źródłem wiedzy na temat zachowania się skały solnej, pozwalającym ocenić trwałość obiektu przy uwzględnieniu szeregu czynników (np. czas, temperatura), są próby pełzania.

Stateczność określa się na podstawie znajomości własności soli, a te wyznacza się laboratoryjnie i w pomiarach in situ (badanie konwergencji). Informacje o geometrii złoża oraz specyfice jego pracy pozwalają dobrać odpowiednie kryterium wytężeniowe dla danego materiału (Kłeczek 1994, Kortas 2008). Kryterium jest dobierane na podstawie znajomości parametrów pełzania, które decydują o finalnym stanie odkształceniowo-naprężeniowym ośrodka solnego jako materiału konstrukcyjnego.

Dla przeprowadzenia geomechanicznej analizy stateczności pola magazynowego czy to za pomocą rozwiązań analitycznych, czy metod analiz numerycznych - niezbędna jest znajomość własności sprężysto-plastyczno-lepkich skały solnej. Wiedza o parametrach wytrzymałościowych skały w trójosiowym stanie naprężenia, parametrach reologicznych wyznaczonych $\mathrm{z}$ badań trójosiowego pełzania soli w podwyższonych temperaturach, wspomaga proces projektowy i pozwala precyzyjnie przewidywać zachowanie projektowanego obiektu oraz jego wpływ na górotwór. W praktyce pełzanie soli przekłada się na zmianę objętości wyrobiska. W warunkach rzeczywistych lepkie pełzanie wywołuje zaciskanie wyrobisk, kawerny wraz z upływem czasu będą traciły swoją objętość i będzie to wpływało na zmniejszenie użyteczności magazynu. Zjawisko pełzania zależy również od temperatur górotworu w otoczeniu kawerny, wytworzonych podczas sprężania i rozprężania gazu, które mogą przyspieszać lub spowalniać proces pełzania.

Prognozowanie stateczności kawerny magazynowej jest skomplikowanym procesem obejmującym rozpatrywanie możliwego zachowania górotworu w szerokim horyzoncie czasowym z uwzględnieniem dodatkowo zmiennej temperatury, ciśnienia górotworu i ciśnienia wewnątrz obiektu. Zjawisko konwergencji może mieć w zależności od przeznaczenia obiektu zarówno negatywny (ubytek objętości kawern magazynowych), 
jak i pozytywny wpływ (izolacja składowanych odpadów w górotworze) w okresie eksploatacji obiektu. Konwergencja nie wpływa na utratę stateczności komór magazynowych i nie rzutuje na bezpieczeństwo eksploatacji pola magazynowego, ale ubytek objętości oznacza zmniejszenie pojemności magazynowych, a więc uszczuplenie rezerw magazynowych. Badania laboratoryjne mające na celu poznanie własności reologicznych są niezbędne, by móc określić kierunek zmian zachodzących w złożu na skutek eksploatacji. Znajomość zjawisk reologicznych i ich intensywności w przypadku planów zagospodarowania części złoża soli zalegającego na monoklinie przedsudeckiej pozwoli optymalnie wykorzystać tę wiedzę na etapie projektowania wielkogabarytowych obiektów przeznaczonych do magazynowania lub składowania.

Publikacja powstała w Akademii Górniczo-Hutniczej w Krakowie, na Wydziale Wiertnictwa, Nafty i Gazu, została sfinansowana z subwencji badawczej nr 16.16.190.779.

\section{Literatura}

Firme P.A.L.P., Roehl D., Romanel C., 2016, An assessment of the creep behaviour of Brazilian salt rocks using the multi-mechanism deformation model, Acta Geotechnica, vol. 11, s. 1445-1463. https://doi.org/10.1007/s11440-016-0451-y.

Flisiak D., Kolano M., 2012, Research on geo-mechanical properties of rock salt in Kłodawa diapir, AGH Journal of Mining and Geoengineering, vol. 36, no. 2, s. 145-152. Kłeczek Z., 1994, Geomechanika górnicza, Śląskie Wydawnictwo Techniczne, Katowice. Kłeczek Z., Filcek H., 1969, Patent nr 57129/1969.

Kortas G., 2008, Ruch górotworu w rejonie wysadów solnych, Wydawnictwo Instytutu GSMiE PAN, Kraków.

Kunstman A., Poborska-Młynarska K., Urbańczyk K., 2002, Zarys otworowego tugownictwa solnego: aktualne kierunki rozwoju, Uczelniane Wydawnictwa Naukowo-Dydaktyczne AGH, Kraków.

Lankof L., 2018, Klasyfikacja polskich złóż soli kamiennej $w$ aspekcie magazynowania i sktadowania substancji, Wydawnictwo Instytutu Gospodarki Surowcami Mineralnymi i Energią PAN, Kraków.

Pałac-Walko B., Pytel W., 2010, Odporność obiektów magazynowych w masywie solnym LGOM na zagrożenie generowane działalnościa górnicza, Cuprum, nr 4(57), s. 59-69. Preidl M., 1990, Dokumentacja geologiczna soli kamiennej występującej ponad złożem rud miedzi Kopalni Sieroszowice, zasoby w kategorii C1 i szacunkowe, Archiwum Państwowe Instytutu Geologicznego-PIB, Warszawa.

Reza Taheri S., Pak A., Shad S., Mehrgini B., Razifar M., 2020, Investigation of rock salt layer creep and its effects on casing collapse, International Journal of Mining Science and Technology, vol. 30, s. 357-365. https://doi.org/10.1016/j.ijmst.2020.02.001. 
Szybist A., 1984, Mapa izopachytowa złoża soli kamiennej najstarszej w LGOM, AGH. Śliwiński A., 2001, Ultradźwięki i ich zastosowania, Wydawnictwa Naukowo-Techniczne, Warszawa.

Ślizowski J., Urbańczyk K., 2011, Możliwości magazynowania gazu ziemnego w Polskich ztożach soli kamiennej w zależności od warunków geologiczno-górniczych, Instytut Gospodarki Surowcami Mineralnymi i Energią PAN, Kraków.

Tajduś A., Cała M., Tajduś K., 2012, Geomechanika w budownictwie podziemnym: projektowanie i budowa tuneli, Wydawnictwa AGH, Kraków.

Zhang Q., Song Z., Wang J., Zhang Y., Wang T., 2021, Creep Properties and Constitutive Model of Salt Rock, Advances in Civil Engineering, vol. 2021, 8867673. https:// doi.org/10.1155/2021/8867673.

Zhou H., Liu D., Lei G., Xue D., Zhao Y., 2018, The Creep-Damage Model of Salt Rock Based on Fractional Derivative, Energies, vol. 11(9), 2349. https://doi.org/10.3390/ en11092349. 